

\section{Daftar Isi (Table of Content) Journal of Government
Civil Society}

\begin{tabular}{|c|c|}
\hline \multirow{3}{*}{$146-163$} & $\begin{array}{l}\text { New Public Management (New Public Comparison Meta-Analysis } \\
\text { Developed and Developing Country Policies) }\end{array}$ \\
\hline & Dyah Mutiarin $^{2}$, Misran ${ }^{1}$ \\
\hline & $\begin{array}{l}\text { (1 Department of Government Affairs and Administration, Universitas Muhammadiyah } \\
\text { Yogyakarta, Indonesia) } \\
\text { (2 Jusuf Kalla School of Government, Universitas Muhammadiyah Yogyakarta, Indonesia) }\end{array}$ \\
\hline \multirow{3}{*}{$164-183$} & $\begin{array}{l}\text { Policy Networks: Actors, Interests, and Power Relations in the Jakarta } \\
\text { Reclamation Project }\end{array}$ \\
\hline & Rizki Hegia Sampurna1,2, Chih-Chieh Chou ${ }^{1}$ \\
\hline & $\begin{array}{l}\text { (' Department of Political Science, National Cheng Kung University (NCKU), Taiwan) } \\
\text { ('2 Department of Public Administration, Universitas Muhammadiyah Sukabumi (UMMI), } \\
\text { Indonesia) }\end{array}$ \\
\hline \multirow{3}{*}{$184-197$} & $\begin{array}{l}\text { National Insights and Youth Political Attitudes in Rural Lampung Against } \\
\text { Negative Campaign }\end{array}$ \\
\hline & Hertanto $^{1}$, Handi Mulyaningsih ${ }^{2}$, Asep Nurjaman ${ }^{3}$ \\
\hline & $\begin{array}{l}\left({ }^{1} \text { Departement of Government Science, Universitas Lampung, Indonesia) }\right. \\
\left({ }^{2} \text { Departement of Sociology, Universitas Lampung, Indonesia) }\right. \\
\left({ }^{3} \text { Departement of Government Science, Universitas Muhammadiyah Malang, Indonesia) }\right.\end{array}$ \\
\hline \multirow{3}{*}{$198-213$} & $\begin{array}{l}\text { Ethnic Identity and Local Politics: Study on Regional Head Election in } \\
\text { Merauke Regency } 2020\end{array}$ \\
\hline & Misran', Wahdania Sardi' ${ }^{1}$, Zuly Qodir ${ }^{1}$ \\
\hline & $\begin{array}{l}\text { (1 Department of Government Affairs and Administration, Jusuf Kalla School of Government, } \\
\text { Universitas Muhammadiyah Yogyakarta, Indonesia) }\end{array}$ \\
\hline \multirow{3}{*}{$214-236$} & $\begin{array}{l}\text { Stakeholder Collaboration Model for Ecotourism Development: A Case } \\
\text { Study from Batu City, East Java Province }\end{array}$ \\
\hline & 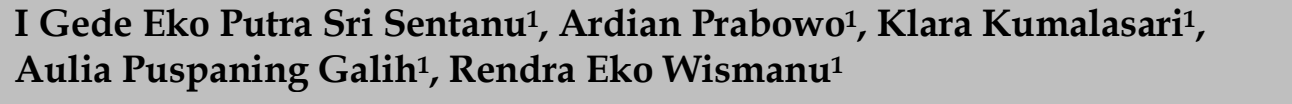 \\
\hline & (' Departement of Public Administration, Universitas Brawijaya, Indonesia) \\
\hline
\end{tabular}


Farmers Social Movement Studies: A Systematic Literature Review for A Conceptual Model

$237-262 \quad$ Wahyudi $^{1}$

(' Department of Sociology, Universitas Muhammadiyah Malang, Indonesia)

Factors Affecting Trust in E-Government

Ulung Pribadi' ${ }^{1}$, Muhammad Iqbal ${ }^{2}$, Fittia Restiane ${ }^{3}$

263 - 276 (1 Post-Graduate Program Universitas Muhammadiyah Yogyakarta, Indonesia)

( ${ }^{2}$ Department of Political Science National Cheng Kung University, Taiwan)

$\left({ }^{3}\right.$ Department of Government Affairs and Administration Universitas Muhammadiyah Yogyakarta, Indonesia) 


\title{
National Insights and Youth Political Attitudes in Rural Lampung Against Negative Campaign
}

\author{
Hertanto $^{1^{*}}$, Handi Mulyaningsih ${ }^{2}$, Asep Nurjaman ${ }^{3}$ \\ ${ }^{1}$ Departement of Government Science, Universitas Lampung, Indonesia \\ ${ }^{2}$ Departement of Sociology, Universitas Lampung, Indonesia \\ ${ }^{3}$ Departement of Government Science, Universitas Muhammadiyah Malang, Indonesia \\ *Email Correspondence: hertanto.1960@fisip.unila.ac.id
}

\begin{abstract}
Social media has become an easy means for spreading fake news, negative content and black campaigns. The purpose of this study is to examine national insight and political attitudes of rural youth towards negative campaigns in general elections and regional head elections. The method used is in-depth interviews through structured focus group discussions (FGD) with students and the younger generation in rural South Lampung. The results showed that they realized the importance of Pancasila as a unifying tool for the nation. The rural youth have national insight and political attitudes against the strategy and spread of negative campaigns with primordial sentiments (ethnicity, religion, race, and intergroup). This finding is very important for maintaining harmony in Lampung and can be a model for other regions in Indonesia.
\end{abstract}

Keywords: National insight, political attitudes, social media, negative campaigns

\begin{abstract}
ABSTRAK
Media sosial menjadi sarana mudah untuk penyebaran berita bohong, konten negatif dan kampanye hitam. Tujuan penelitian ini untuk mengkaji wawasan kebangsaan dan sikap politik generasi muda perdesaan terhadap kampanye negative dalam pemiliham umum dan pemilihan kepala daerah. Metode yang digunakan adalah wawancara mendalam melalui diskusi kelompok terfokus (FGD) terstruktur dengan mahasiswa dan generasi muda di perdesaan Lampung Selatan. Hasil penelitian menunjukkan bahwa mereka menyadari pentingnya Pancasila sebagai alat pemersatu Bangsa. Generasi muda perdesaan memiliki wawasan kebangsaan dan sikap politik menolak terhadap strategi dan penyebaran kampanye negative yang bernuansa sentimen primordial (suku, agama, ras, dan antargolongan). Temuan ini sangat penting untuk menjaga kerukunan di Lampung dan dapat menjadi model bagi daerah lain di Indonesia.
\end{abstract}

Kata Kunci: Wawasan kebangsaan, sikap politik, media sosial, kampanye negatif

\section{INTRODUCTION}

The challenge of elections in the era of information and communication technology (ICT) is the development of hoaxes and black campaigns (Djuyandi et al., 2018); (Purnawati \& Fajar, 2019); (Nisa et al., 2020); (Turistiati, 2016). Meanwhile, today's youth are the millennial generation who are tied to social media (Arisandy et al., 2019); (Juditha \& Darmawan, 2018); (Rais et al., 2018); (Achmad et al., 2020). Furthermore, young people are the most active part of society, the future of the country is in their hands. Therefore,

Citation : Hertanto, Mulyaningsih, H., \& Nurjaman, A. (2021). National Insights and Youth Political Attitudes in Rural Lampung Against Negative Campaign. Journal of Government and Civil Society, 5(2), 184-197. https:// doi.org/10.31000/jgcs.v5i2.4110 
youth studies are relevant and relevant as research material. National insight (Barida, 2017); (Muladi, 2019); (Tachyudin et al., 2020); (Widisuseno \& Sudarsih, 2019) and youth political attitudes occupy a special place in youth studies.

Regarding media use among youth, a study of 100 youth Facebook users in Nigeria to see the relationship between political attitudes and political participation. The results showed a significant relationship between the use of Facebook and political participation (Dagona et al., 2013). However, another empirical study conducted on 768 students in Moscow using four indicators, namely value, emotional, cognitive, and strategic, showed that students in Moscow were young citizens who had low political interest and were less active in politics(Litvinova et al., 2020). This shows that there are differences in political attitudes between youth in developing and developed countries.

However, national insight cannot grow by itself, but learning needs to be processed early. Awareness of the need for unity and integrity resulted from knowledge of the reality of a heterogeneous nation, which gave birth to a sense of love for the homeland. The implementation of national insight into the dynamics of Indonesia's political history in education is implemented by internalizing community values such as respect for differences, cooperation, love for the homeland, tolerance, freedom of responsibility, and solidarity (Setiawan et al., 2020). Furthermore, ethnically polarized developing countries usually have high levels of intra-ethnic social capital but low levels of inter-ethnic social capital that can trigger conflict. Violent conflict can be avoided by strengthening interethnic social capital (Miedema, 2010).

Moreover, Indonesia, as a country with a large young generation (Novrizaldi, 2021); (Dewi et al., 2021), we assume that there is no difference in national insight between urban and rural areas. Since many information technology devices such as television and cell phones have been accessed anywhere, information can reach all corners of the region in Indonesia. In addition, the rapid development of information technology (Espino-Díaz et al., 2020); (Rahiem, 2020); (Tropea \& De Rango, 2020). allows the rural youth to access various information and knowledge easily. This fact is exploited by political parties, candidates (executive and legislative), and successful teams in winning general election campaigns (elections) and regional head elections. Candidates in elections convey their campaigns through advertisements in print mass media, electronic mass media, social media, or online media. This social media campaign is regulated in General Election Commission (KPU) Regulation Number 13 of 2020, which stipulates that political parties or coalitions of political parties, candidate pairs, campaign teams, and other parties prioritize the campaign method of limited meetings and face-to-face meetings and dialogue through social media (including online media). 
The importance of this regulation is linked to the 2018 simultaneous regional elections in 171 regions covering 17 provinces, 39 cities, and 115 districts. In 2019 there will be simultaneous general elections that elect DPR, DPD, DPRD, and elect the president and vice president directly. Meanwhile, the Regional Head Election (Pilkada) 2020 ((Marisa et al., 2020); (Gelgel et al., 2020); (Wasisto \& Prayudi, 2020) will be held in 270 regions consisting of 9 provinces, 224 regencies, and 37 cities (Ristyawati, 2020). Meanwhile, eight are held in Lampung Province, namely in Bandar Lampung City, Metro City, South Lampung Regency, Central Lampung Regency, East Lampung Regency, Way Kanan Regency, Pesawaran Regency, and Pesisir Barat Regency. This five-year democracy event was originally scheduled to be held in September 2020 but was later postponed to December 9, 2020, due to the Covid-19 Pandemic (International Institute for Democracy and Electoral, 2020); (Rapeli \& Saikkonen, 2020).

These three political events challenge the future of national and local democracy in provinces, districts, and cities. The politicization of religion, ethnicity and primordial sentiments can threaten the consolidation of democracy (Pamungkas \& Arifin, 2019). However, in implementing campaigns using social media, hoaxes and black campaigns are unavoidable with ethnic, religious, racial, and intergroup nuances (Juditha, 2019). This is contrary to the campaign rules from the KPU. In this case, Juditha (2019) said that social media is an easy means to spread fake news, negative content, and black campaigns. Therefore, there need to be regulations, but the KPU has not regulated the dissemination of campaign content, which people outside the campaign team can do due to the rise of negative campaigns, black campaigns, hoaxes, and hate speech with nuances of primordial sentiments can lead to socio-political vulnerability, intolerance, discrimination, and the potential to divide society (Ekawati et al., 2019).

In a pluralistic society (Pamungkas \& Arifin, 2019), the number of hoaxes and negative campaigns with primordial nuances is very dangerous for the Lampung people, especially young people who are easily provoked. Many cases of conflict involving rural youth in Lampung Province stem from primordial issues such as ethnicity, religion, and between groups. Thus, nationality and political attitudes play a very important role in responding to the spread of hoaxes (fake news), black campaigns, negative campaigns, and hate speech (intolerance) on social media. For this reason, it is important to examine how the political insight of the young generation in rural areas regarding ideology, solidarity, and election campaigns. This research is very important because it can increase knowledge related to handling conflicts in multi-ethnic Indonesia. In addition, the government also needs to pay attention to content related to ethnicity, race, religion on social media not to ignite conflict. 


\section{RESEARCH METHOD}

This study uses a quantitative method with a descriptive approach. A descriptive study in which the researcher tested the relationship between variables only once during the study. This research is based on empirical experience that collects data in numbers that can be calculated and in numeric form. The constructionist critical paradigm approach is expected to provide empowerment and awareness, both for the community and rural youth, about their rights and obligations in the political communication process.

This study uses primary data and secondary data. Primary data was obtained through a questionnaire from 47 people consisting of 20 women and 27 men. While the sample criteria are teenagers, students aged between 15 to 19 years, with a high school education level, and domiciled in Natar District, South Lampung Regency. In-depth interviews also carried out data collection to seek information related to the transformation of national values that could be obtained. While secondary data is obtained through documentation studies, particularly related literature searches in articles, books, and document data on election results.

Data from interviews and questionnaires were grouped, tabulated, and analyzed for further conclusions to be drawn after cross-checking the data. Data analysis uses a Likert Scale which, according to Sugiyono (2020), is used to measure attitudes, opinions, and perceptions of a person or group of people about social phenomena. Each answer is given a score, so the respondent must describe or support the statement (Sugiyono, 2020).

In this study, the national insight is detailed in indicators of knowledge about (1) Pancasila as the ideology of the nation; (2) Insights into the spread of hate speech with primordial sentiments and intolerance on social media; (3) Insights into the spread of state anti-ideology campaigns on social media; (4) Insights into the spread of campaigns against the prevailing political system. National insight is also detailed in indicators of knowledge about the diversity and plurality of the population of Indonesia and Lampung, as well as tolerance and social solidarity.

\section{RESULTS AND DISCUSSION National Insight}

In general, the knowledge of the rural young generation about national and state insights tends to be good. Their political insight towards Pancasila as the state ideology is shown through negative attitudes towards the spread of hate speech with nuances of ethnic, religious, racial, and intergroup sentiments; and intolerance. The majority of respondents disagreed (74.47\%), disagreed (6.38\%), and strongly disagreed $(2.13 \%)$ (See table 1). This national political insight is also supported by the respondents' disapproval of the spread of the anti-ideology campaign of the state (Pancasila) on social media, namely disagreeing $(68.01 \%)$, disagreeing (10.64\%), and strongly disagreeing $(6.38 \%)$. 
According to (Muladi, 2019) the national perspective is the perspective of the Indonesian nation regarding itself and its environment, prioritizing regional unity and unity in the implementation of social, national, and state life. Meanwhile, according to (Tim Pokja Lemdiklat Polri, 2018), the national perspective includes: developing an attitude of pluralism and human rights for Indonesian unity; Indonesia's participation in foreign policy; and carrying out political commitments to government institutions and political parties.

Table 1. National Insight on State Ideology and Primordialism

\begin{tabular}{|c|c|c|c|c|c|c|}
\hline \multirow{2}{*}{ National Insights } & \multicolumn{6}{|c|}{ Respondents' Answers } \\
\hline & 1 & 2 & 3 & 4 & 5 & 6 \\
\hline $\begin{array}{l}\text { Insights into the spread of primordial } \\
\text { sentiment and intolerance on social media }\end{array}$ & $0 \%$ & $10.64 \%$ & $66.38 \% 7$ & $74.47^{\circ}$ & $\% 2.13^{\circ}$ & $5.38 \%$ \\
\hline $\begin{array}{l}\text { Insights into the spread of state anti-ideology } \\
\text { campaigns on social media }\end{array}$ & $4.26 \%$ & $9 \%$ & $10.64 \%$ & $32 \%$ & $6.38^{\circ}$ & $2.13 \%$ \\
\hline $\begin{array}{l}\text { The insight into the spread of the campaign } \\
\text { rejects the prevailing political system }\end{array}$ & $6.38 \%$ & $6.38 \%$ & $6.38 \% 7$ & $74.47^{\circ}$ & $\% 4.26^{\circ}$ & $2.13 \%$ \\
\hline $\begin{array}{l}\text { Pancasila is the state ideology as a unifying } \\
\text { tool for the Indonesian nation. }\end{array}$ & $85.11 \%$ & $14 \%$ & - & - & - & - \\
\hline
\end{tabular}

\section{Source: Research Data Analysis}

Note: $1=$ Strongly Agree; $2=$ Agree; 3 = Disagree; 4 = Disagree; $5=$ Strongly Disagree; $6=$ No Answer

The national insight (Table 1) is in line with the respondent's attitude towards the spread of the campaign against the prevailing political system (anti-Republic of Indonesia) on social media, namely disagreeing $(74.47 \%)$, disagreeing $(6.38 \%)$, and strongly disagreeing. Agree (4.26\%). The statement supports even this political attitude perspective that Pancasila is a unifying tool for the Indonesian nation as the state ideology. The majority of respondents strongly agreed $(85.11 \%)$ and agreed $(14.89 \%)$, and not a single respondent expressed disagreement (See table 1). Thus Pancasila, as the ideology of the nation and state, has strong legitimacy among the rural youth generation. Ideology is a set of attitudes, beliefs, and values related to human nature and society that drive their behavior in political, economic, and social affairs (Plano et al., 1989). This fact is also supported by findings that explain a correlation between the understanding of nationality and the attitude or character of youth (Kusmayadi, 2017). 


\section{Social Solidarity}

Social solidarity is an emotional and moral feeling formed in relationships between individuals or groups based on mutual trust, common goals and ideals, solidarity, and a sense of acceptance (Riadi, 2018). Solidarity is a characteristic of feeling solidarity, one feeling the same fate, and a feeling of loyalty from friends among fellow members of society, which is very necessary for the life of society, nation, and the state as citizens of a nation-state.

Table 2. National Insight on Social Solidarity

\begin{tabular}{|c|c|c|c|c|c|c|}
\hline \multirow{2}{*}{ Statement } & \multicolumn{6}{|c|}{ Respondents' Answers } \\
\hline & 1 & 2 & 3 & 4 & 5 & 6 \\
\hline $\begin{array}{l}\text { Indonesia is a pluralistic society in the social, } \\
\text { cultural, religious, ethnic, cultural and } \\
\text { linguistic sectors. }\end{array}$ & $74.46 \%$ & $19.14 \%$ & - & - & - & $6,63 \%$ \\
\hline $\begin{array}{l}\text { The people of Lampung are a pluralistic } \\
\text { society in the social, cultural, religious, ethnic, } \\
\text { cultural, and linguistic fields. }\end{array}$ & $27.65 \%$ & $70.21 \%$ & - & - & - & $2.21 \%$ \\
\hline $\begin{array}{l}\text { I feel comfortable neighbors with people of } \\
\text { other religions. }\end{array}$ & $6.63 \%$ & $51.06 \%$ & $34.04 \%$ & & $6.63 \%$ & $2.21 \%$ \\
\hline $\begin{array}{l}\text { I feel comfortable neighbors with people of } \\
\text { different ethnicities. }\end{array}$ & $2.21 \%$ & $65.96 \%$ & $31.91 \%$ & & - & - \\
\hline
\end{tabular}

\section{Source: Research Data Analysis}

Note: $1=$ Strongly Agree; 2= Agree; 3 = Disagree; 4 = Disagree; $5=$ Strongly Disagree; 6 = No Answer

The national political insight of the rural young generation towards social solidarity is shown through a positive attitude towards the diversity (plurality) of the Indonesian nation and the people of Lampung. The majority strongly agree $(74.47 \%)$ and agree $(19.15 \%)$ that the Indonesian population is a diverse society in social, cultural, religious, ethnic, customs, and language fields. At the same time, the rest did not answer $(6.38 \%)$ (See table 2). 
The statement also supports this national political insight that the people of Lampung are a diverse society in the social, cultural, religious, ethnic, customary, and linguistic fields. Most respondents stated that they strongly agree (27.66\%) and agree $(70.21 \%)$. At the same time, the rest did not answer (6.38\%) (See table 2).

This national political perspective is also supported by the statement that they feel comfortable neighbors with members of other religions. The majority of respondents strongly agreed (6.38\%) and agreed (51.06\%). Thus, most of them realize that the people of Indonesia and Lampung are diverse communities in the social, cultural, religious, ethnic, customary, and linguistic fields (See table 2). This national political insight is also supported by the statement that they feel comfortable neighbors with people of different ethnic groups. The majority of respondents strongly agreed $(6.38 \%)$ and agreed $(65.97 \%)$ to be neighbors with different ethnicities. At the same time, others disagree (31.91\%) (See table 2).

\section{Political Attitudes Toward Black and Negative Campaigns}

Political attitudes are a reaction to a feeling of individual psychological tendencies in the form of support/agree or reject/disagree, which becomes collective behavior in a political system. In other words, political attitudes are the perception of a person or group to respond to political problems around them by supporting (pro) or rejecting (contra). Attitudes shape the way a person or group feels and responds to political symptoms.

Attitude links various inherent beliefs and encourages a person to respond to an object or situation in a certain way. Political attitudes depend on political issues, leaders, ideas, institutions, or events (Plano et al., 1989). Attitudes may not manifest in real political actions, but attitudes tend to change over time, change circumstances, and are influenced by various motives (Hatemi \& Verhulst, 2015).

Meanwhile, the campaign is political communication to make the names of candidates and political parties better known by their constituents. Campaign relates to how a candidate packs the content of his campaign message so that it interpreted as an achievement by the audience to make an image. The campaign's content is generally about the work program, vision, and mission of the candidate or political party. Campaign media in lectures, propaganda, advertisements in mass media, social media, leaflets, brochures, and flyers. However, in practice, there is often a form of communication that emphasizes the weakness of the opponent is arguing, behaving, personality, and his ability to rule (Lilleker, 2006), which is later known as negative campaigning or campaigns that attack other candidates or political parties who are opponents in a contest whose contents are lies without facts, this is what is then called the black campaign (Doly, 2020). 
Social media is the most often used to spread negative campaigns. Social media is the most widely used negative campaign tool in terms of its massive reach and use by all levels of society (Irawan, 2019). The rural young generation gets information about general election campaign and regional head elections, including social media. According to respondents, social media is most often used to spread hate speech with nuances of ethnic, religious, racial, and intergroup sentiments; and intolerance is Facebook (FB) $76.59 \%$. The rests are Twitter and Instagram. Meanwhile, the social media that most frequently spread campaigns against the prevailing political system was Facebook (76.59\%).

In this study, political attitudes towards black and negative campaigns by candidates (executive and legislative) and political parties, in general elections or regional head elections, are detailed in the assessment indicators of younger generation of (1) campaign strategies of political parties or candidates using primordial issues and ethnic, racial, religious, ethnic sentiments; (2) the strategy of political parties or candidates using negative campaigns that spread personal or group disgrace, tarnish and horror; and (3) the strategy of political parties or candidates using "black" campaigns that spread lies and slander.

The political attitude of the majority of respondents stated that they strongly disagreed $(27.66 \%)$ and disagreed $(48.94 \%)$. Meanwhile, the rest agreed $(21.28 \%)$ and did not answer $(2.28 \%)$. This political attitude is also supported by the statement of the majority of respondents who strongly disagree $(57.46 \%)$ and disagree $(38.29 \%)$ with the political party/candidate strategy that uses negative campaigns (spreading disgrace and personal ugliness). At the same time, the rest agreed (4.26\%) (See table 3).

This national political attitude insight was also supported by the statement of the majority of respondents who strongly disagreed $(74.47 \%)$ and disagreed $(23.40 \%)$ on the strategy of political parties/candidates using "black" campaigns (spreading lies and slander). In contrast, the rest agreed $(2.13 \%)$. Thus, the national political insight of the rural youth generation is in a good category. 
Table 3. Political Attitudes toward Black and Negative Campaigns

\begin{tabular}{|c|c|c|c|c|c|c|}
\hline \multirow{2}{*}{ Campaign Strategy } & \multicolumn{6}{|c|}{ Attitude of Respondents } \\
\hline & 1 & 2 & 3 & 4 & 5 & 6 \\
\hline $\begin{array}{l}\text { The campaign strategy of political parties } \\
\text { or candidates uses primordial issues and } \\
\text { sentiments of ethnicity, race, religion, } \\
\text { ethnicity }\end{array}$ & - & $21.28 \%$ & $48.94 \%$ & - & $27.66 \%$ & $2.13 \%$ \\
\hline $\begin{array}{l}\text { The strategy of political parties or } \\
\text { candidates uses negative campaigns that } \\
\text { spread disgrace, tarnish, and badness of } \\
\text { individuals or groups }\end{array}$ & - & $4.26 \%$ & $38.30 \%$ & - & $54.45 \%$ & - \\
\hline $\begin{array}{l}\text { The political party or candidate strategy } \\
\text { uses a "black" campaign that spreads lies } \\
\text { and slander. }\end{array}$ & $2.13 \%$ & - & $23.40 \%$ & - & $74.47 \%$ & - \\
\hline
\end{tabular}

\section{Source: Research Data Analysis}

Note: 1= Strongly Agree; 2= Agree; 3 = Disagree; 4 = Disagree; $5=$ Strongly Disagree; 6 = No Answer

The phenomenon of national insight and the political attitude of the rural youth generation above shows a positive perception of the prevailing political system in Indonesia. They support the state ideology, with tolerance and solidarity towards the diversity of fellow citizens and local citizens, without being based on primordial negative sentiments. On the contrary, they show negative attitudes by rejecting the black and negative campaign campaigns by political parties and candidates in the general and regional head elections.

Elections and regional head elections involve citizens in the political process, knowledge of their influence on public attitudes towards government, and the role of individuals, which have important implications for the democratic government system. This form of individual and collective participation has an equally strong socializing effect, while the relationship between participation and attitudes is reciprocal (Quintelier \& Hooghe, 2012). Political attitudes are feelings that can influence individual and group political actions and can impact the political process.

The rise of negative campaigns and black campaigns cannot be avoided in general elections in Indonesia. It cannot be denied that the black campaign has a very, very bad impact on the political education of the community, especially the younger generation. 
The phenomenon that occurs is the use of ethnicity, religion, race, and intergroup issues in politics. The issue of religion is familiar in every general election and regional head election. It raises several perspectives and the assumption that all of these are a form of politicizing religion or the embodiment of religious values in politics.

There must always be differences of opinion in a pluralistic society such as in Lampung. The differences and diversity that exist in Lampung can lead to conflict and division if not addressed wisely. On the other hand, plurality and solidarity can become the glue in society if they are managed properly without uniformity. Therefore, it is hoped that the public and the younger generation will always respond carefully and intelligently to all the news they get, whether negative campaign campaigns or black campaigns. Thus, every implementation of electoral democracy in the regions can be realized honestly, fairly, directly, publicly, freely, secretly, and with integrity. All parties involved should be able to maintain harmony in the life of the nation and state. Society, government, political parties, candidates, election organizers, and the younger generation must be clever at digesting the information obtained. It is hoped that it will not be easily provoked for the sake of national integration.

The spread of fake news or hoaxes is thought to be a new model to become a new campaign model for the formation of political opponents in general elections and regional head elections (Wahyu, 2021). Social media plays a significant role in the 2020 regional elections because of the Covid-19 pandemic situation. Advertising and social media content can be directed to specific areas to influence voter attitudes and behavior.

However, the people of Lampung have local wisdom that can ward off various provocations against negative campaigns and black campaigns. The people of Lampung have the motto "Sai (Sang) Bumi Ruwa Jurai," which is the basis for local wisdom in the life of society, nation, and state. The phrase Sai Bumi Ruwa Jurai is also used as the slogan of Lampung Province, which in Indonesian means "one earth, two kinds"(Nastiti, 2018). In general, local wisdom can be understood as local ideas that are wise, full of wisdom, of good value, which are embedded and followed by members of the community.

The slogan Sai Bumi Ruwa Jurai is interpreted as a spirit of unity and mutual respect in the Lampung tribal community, both from Saibatin and Pepadun, advancing Lampung Province as the home of the Lampung people. The phrase ruwa jurai also refers to the kinship relationship between the indigenous people of Lampung and the immigrants who live in Lampung Province. The immigrants come from Javanese, Sundanese, Balinese, South Sumatra, Batak, Minang, Chinese, and Bugis ethnic groups(Pahrudin \& Hidayat, 2010). In this case, this kinship becomes a spirit of unity between the natives and immigrants to build Lampung Province. This local wisdom, among other things, affects the national insight and political attitudes of the Lampung rural generation towards negative campaigns and social solidarity. 
This local wisdom of Lampung is in line with the multiculturalism of Indonesia, which is based on the concept of "Bhineka Tunggal Ika." On the one hand, Indonesia recognizes the "pluralist model" by recognizing the rights of various ethnic-cultural groups to maintain their respective identities. On the other hand, Indonesia also anticipates the "cosmopolitan model" by encouraging individuals from various identity groups to interact and participate in the public space by upholding beliefs, values, symbols, and citizenship consensus (Latif, 2021).

\section{CONCLUSION}

Lampung is an area rich in cultural, ethnic, racial, linguistic, religious and regional diversity. Therefore, Lampung, like Indonesia, does not only need formal rules but also needs social capital, namely national insight in realizing unity and integrity. The findings of this study indicate that the younger generation in South Lampung has a high level of national insight. This will have implications for harmonization between groups that can create stability and social integration in Lampung. Furthermore, the existence of high social capital of inter-group harmony will have implications for the elite to be more moderate in politics, so that black campaigns and hoaxes can be anticipated when the election takes place.

The findings of this study are also in line with the Lampung people's "Sang Bumi Ruwa Jurai" which is the basis for local wisdom in the life of society, nation and state. The slogan "Sang Bumi Ruwa Jurai" is interpreted as a spirit of unity and mutual respect in the Lampung tribal community, both Saibatin and Pepadun, in advancing Lampung Province as a common home for the Lampung people. The phrase ruwa jurai also refers to the kinship relationship between the indigenous people of Lampung and other residents who come and settle in Lampung Province.

\section{REFERENCES}

Achmad, R. W., Poluakan, M. V., Dikayuana, D., Wibowo, H., \& Raharjo, S. T. (2020). Potret Generasi Milenial Pada Era Revolusi Industri 4.0. Focus/ : Jurnal Pekerjaan Sosial, 2(2), 187. https://doi.org/10.24198/focus.v2i2.26241

Arisandy, D., Rizkika, D. P., \& Astika, T. D. (2019). Eksistensi Bahasa Indonesia Pada Generasi Milenial Di Era Industri 4.0. Pendidikan Bahasa Dan Sastra Indonesia, 3(2), 247-251. garuda.ristekbrin.go.id

Barida, M. (2017). Inklusivitas Vs Eksklusivitas: Pentingnya Pengembangan Wawasan Kebangsaan Dalam Mewujudkan Kedamaian Yang Hakiki Bagi Masyarakat Indonesia. Universitas Ahmad Dahlan, 5(February), 1403-1409. http://lpp.uad.ac.id/ wp-content/uploads/2017/05/268-MUYA-BARIDA1403-1409.pdf 
Dagona, Z. K., Karick, H., \& Abubakar, F. M. (2013). Youth Participation in Social Media and Political Attitudes in Nigeria. Journal of Sociology, Psychology and Anthropology in Practice, 5(1), 1-7.

Dewi, S., Listyowati, D., \& Napitupulu, B. E. (2021). Bonus Demografi di Indonesia: Suatu Anugrah atau Petaka. Journal of Information System, Applied, Management, Accounting and Research, 2(3), 17-23.

Djuyandi, Y., Herdiansah, A. G., \& Alkadrie, J. F. (2018). Sosialisasi Dampak Negatif Black Campaign Terhadap Keamanan Pemilihan Kepala Daerah Tahun 2018 di Provinsi Jawa Barat. Jurnal Pengabdian Kepada Masyarakat, 2(7), 581-584.

Doly, D. (2020). Penegakan Hukum Kampanye Hitam (Black Campaign) Di Media Sosial: Pembelajaran Pemilihan Umum Presiden Tahun 2019. Kajian, 25(I), 1-18. http:// jurnal.dpr.go.id/index.php/kajian/article/view/1885

Ekawati, E., Hanafi, R. I., Soebhan, S. R., Sambodo, M. T., Yanuarti, S., Raharjio, S. N. I., Haripin, M., Mengko, D. M., \& Aisah Putri Budiatri. (2019). Peta Sosial Politik Menjelang Pemilu Serentak 2019: Survei Pandangan Ahli (pp. 1-250). LIPI Press. https://eservice.lipipress.lipi.go.id/press/catalog/book/211

Espino-Díaz, L., Fernandez-Caminero, G., Hernandez-Lloret, C. M., Gonzalez-Gonzalez, H., \& Alvarez-Castillo, J. L. (2020). Analyzing the impact of COVID-19 on education professionals. Toward a paradigm shift: ICT and neuroeducation as a binomial of action. Sustainability (Switzerland), 12(14), 1-10. https://doi.org/10.3390/su12145646

Gelgel, N. M. R. A., Apriani, K. D., \& Ginting, R. T. (2020). Communication Strategies in the 2020 Local Election Stages Socialization During the Covid-19 Pandemic. Jurnal Komunikasi Ikatan Sarjana Komunikasi Indonesia, 5(2), 10-17.

Hatemi, P. K., \& Verhulst, B. (2015). Political attitudes develop independently of personality traits. PLoS ONE, 10(3), 134072. https://doi.org/10.1371/ journal.pone.0118106

International Institute for Democracy and Electoral. (2020). Elections and COVID-19. International IDEA Technical, 1, 1-5. https://doi.org/10.31752/idea.2020.11

Irawan, F. D. (2019). Pengaruh Terpaan Kampanye Negatif di Instagram Terhadap Partisipasi Politik Pemilih Pemula. Universitas Muhammadiyah Malang. http:// eprints.umm.ac.id/53365/

Juditha, C. (2019). Buzzer di Media Sosial Pada Pilkada dan Pemilu Indonesia Buzzer in Social Media in Local Elections and Indonesian Elections. Prosiding Seminar Nasional Komunikasi Dan Informatika, 3, 199-212. https://jurnal.kominfo.go.id/index.php/snki/ article/view/2557/1255

Juditha, C., \& Darmawan, J. (2018). Penggunaan Media Digital dan Partisipasi Politik Generasi Milenial. Jurnal Penelitian Komunikasi Dan Opini Publik, 22(2), 94-109. https:/ /jurnal.kominfo.go.id/index.php/jpkop/article/view/1628 
Kusmayadi, Y. (2017). Hubungan Antara Pemahaman Sejarah Nasional Indonesia dan Wawasan Kebangsaan Dengan Karakter Mahasiswa (Studi Pada Mahasiswa Pendidikan Sejarah FKIP Universitas Galuh Ciamis). Agastya: Jurnal Sejarah Dan Pembelajarannya, 7(2), 1. https://doi.org/10.25273/ajsp.v7i2.1486

Latif, Y. (2021). Berkaca Dari Amerika. Kompas, Surat Kabar Harian.

Lilleker, D. (2006). Key Concepts in Political Communication (SAGE Key Concepts series). Sage Publication.

Litvinova, T., Vershinina, O., \& Moskvitin, G. (2020). Social and political attitudes of moscow students on the background of the all-russia and regional youth studies. Social Sciences, 9(9), 1-18. https://doi.org/10.3390/socsci9090153

Marisa, H., Pornauli, A., Indra, A., \& Aurora, A. (2020). The Regional Head Elections (Pilkada) 2020 During Covid-19 Pandemic: A Projection. JOELS: Journal of Election and Leadership, 1(2), 64-68. https://doi.org/10.31849/joels.v1i2.4424

Miedema, T. E. (2010). Violent conflict and social capital in ethnically-polarized developing countries. ProQuest Dissertations and Theses, 440. https://search.proquest.com/ dissertations-theses/violent-conflict-social-capital-ethnically/docview/870476690/ se2 ? accountid $=41849$

Muladi. (2019). Wawasan Kebangsaan (4 Konsesus Dasar Berbangsa dan Bernegara).

Nastiti, L. B. (2018). Lampung, Provinsi dengan Dua Suku Masyarakat yang Berbeda. Dirjen Kebudayaan Kemdikbud.

Nisa, C. U., Disemadi, H. S., \& Roisah, K. (2020). Aspek Hukum Tentang Black Campaign Pada Platform Media Sosial Instagram. Mahkamah/ : Jurnal Kajian Hukum Islam, 5(121), 1. https:// doi.org/10.24235/mahkamah.v5i1.6032.g2966

Novrizaldi. (2021). Hasil Survei Penduduk 2020 Peluang Indonesia Maksimalkan Bonus Demografi. Kemenko PMK. https://www.kemenkopmk.go.id/hasil-survei-penduduk2020-peluang-indonesia-maksimalkan-bonus-demografi

Pahrudin, A., \& Hidayat, M. (2010). Budaya Lampung dan Penyelesaian Konflik Sosial Keagamaan. Pustaka Ali Imron.

Pamungkas, A. D., \& Arifin, R. (2019). Demokrasi Dan Kampanye Hitam Dalam Penyelenggaraan Pemilu Di Indonesia. Jurnal Syariah Dan Hukum, 17(9), 16-30.

Plano, J. C., Riggs, R. E., \& Robbin, H. S. (1989). Kamus Analisa Politik. CV Rajawali.

Purnawati, L., \& Fajar, E. N. (2019). PERAN KPU DALAM MENGATASI BLACK CAMPAIGN ( Studi Pada 1 Kantor KPU 1 Kabupaten. Jurnal Publiciana, 13(1), 29-51. https:// doi.org/10.36563/p.v13i1.204

Quintelier, E., \& Hooghe, M. (2012). Political attitudes and political participation: A panel study on socialization and self-selection effects among late adolescents. International Political Science Review, 33(1), 63-81. https:// doi.org/10.1177/0192512111412632 
Rahiem, M. D. H. (2020). Technological barriers and challenges in the use of ICT during the COVID-19 emergency remote learning. Universal Journal of Educational Research, 8(11B), 6124-6133. https://doi.org/10.13189/ujer.2020.082248

Rais, N. S. R., Dien, M. M. J., \& Dien, A. Y. (2018). Kemajuan Teknologi Informasi Berdampak Pada Generalisasi Unsur Sosial Budaya Bagi Generasi Milenial. Jurnal Mozaik, 10(2), 61-71.

Rapeli, L., \& Saikkonen, I. (2020). How will the COVID-19 pandemic affect democracy? Democratic Theory, 7(2), 25-32. https://doi.org/10.3167/DT.2020.070204

Riadi, M. (2018). Pengertian, Jenis dan Bentuk Solidaritas Sosial. Kajianpustaka.Com.

Ristyawati, A. (2020). Efektivitas Pelaksanaan Pilkada Serentak 2020 Pada Masa Pandemi Darurat Covid-19 Di Indonesia. Crepido, 2(2), 85-96. https://doi.org/10.14710/ crepido.2.2.85-96

Setiawan, J., Aman, \& Wulandari, T. (2020). Understanding Indonesian history, interest in learning history and national insight with nationalism attitude. International Journal of Evaluation and Research in Education, 9(2), 364-373. https://doi.org/10.11591/ ijere.v9i2.20474

Sugiyono. (2020). Metode Penelitian Kuantitatif, Kualitatif, dan Kombinasi (Mixed Methods) (Sutopo (ed.); Revisi). Alfabeta.

Tachyudin, M., Cahyono, H., \& Utami, P. S. (2020). Penguatan Civic Literasi Dalam Membentuk Wawasan Kebangsaan. Civic-Culture: Jurnal Ilmu Pendidikan PKn Dan Sosial Budaya, 4(2), 31-39. http:/ / publikasi.stkippgri-bkl.ac.id/index.php/CC/article/view/ 434

Tim Pokja Lemdiklat Polri. (2018). Bela Negara (Handayani, N. Widyayoko, D. Rusdian, \& A. A. Susanto (eds.)). Lembaga Pendidikan dan Pelatihan Polri.

Tropea, M., \& De Rango, F. (2020). COVID 19 in Italy: current state, impact and ICT based solutions. IET Smart Cities, 2(2), 74-81. https://doi.org/10.1049/ietsmc. 2020.0052

Turistiati, A. T. (2016). Fenomena Black Campaign Dalam Pemilihan Kepala Daerah 2015. Transparansi Jurnal Ilmiah Ilmu Administrasi, 8(2), 208-215. https://doi.org/ 10.31334/trans.v8i2.72.g64

Wahyu. (2021). Melawan Hoaks Pemilu. Kompas.

Wasisto, A., \& Prayudi. (2020). Antisipasi Implikasi Demokratis Pilkada Serentak Tahun 2020. Info Singkat DPR, 12(No. 12), 28. https:/ / sdip.dpr.go.id/search/detail/category/ Info Singkat/id/1080

Widisuseno, I., \& Sudarsih, S. (2019). Penguatan Wawasan Kebangsaan Sebagai Upaya Pencegahan Paham Radikalisme Dan Intoleransi Di Kalangan Pelajar Sekolah Menengah Atas Negeri 3 Salatiga Kotamadia Salatiga. Harmoni, 3(1), 24-28. 